\title{
WORLD JUSTICE, SOCIALISM, AND THE INTELLECTUALS
}

\author{
FRANK H. KNIGHT*
}

I

$\mathrm{T}$

$1 \mathrm{HE}$ editors' rash invitation to comment on Professor Hayek's article, with a suggestion of side-glances (sideswipes?) at the papers on world government, is accepted because of the writer's conviction of the vital importance of some "fundamentals" in this area that are being rather ingeniously avoided all around. To begin with, let me note the appropriateness of juxtaposing these two themes in the same issue of a learned journal. The close connection is one of the things likely to be overlooked. It is not merely that nationalistic sentiment (or sentimental nationalism, patriotism, called the last refuge of a scoundrel) provides the main reason or impetus toward world government; there are deeper reasons why economic stateism calls for an omnipotent world state.

Effective utilization of modern technology requires a large amount of world-wide specialization and co-ordination. The nation-states into which the brute force and accidents of history have divided the globe are far too few and too uneven in size, resources, and industrial development to form an effective market for trade as units, even if they were so inclined, i.e., if they were not like the pressure groups, primarily out to take advantage of one another. (Under the euphemistic name of influencing the terms of trade, this is an outstanding feature in the policy of west-European nations today.) Moreover, as the advocates of the "social welfare state" seem strangely unwilling to see, to the extent that they may succeed in approaching some ideal of "justice" within particular countries or areas, this must raise or intensify the same problems of "exploitation" between units. Economic justice will not stop at political boundaries; and the spokesman of the "disadvantaged" countries are not now ignoring this fact, any more than the spokesmen of the disadvantaged classes keep silent in countries where the poorest enjoy a minimum of comfort and security far above what is possible for the world as a whole. The socialist state (or any welfare state) must be a world state.

In the second place, advocating world government is also in large part

* Morton D. Hull Distinguished Service Professor of Social Sciences and Philosophy, University of ${ }_{+}^{*}$ Chicago. 
an indoor sport of the intellectuals, and it displays the same kind of "thinking." Both reflect the current fad, or craze, for fixing anything that seems to be wrong in the world by passing a law and setting up a political authority with plenary power. ${ }^{x}$ Reformers hardly ask how long an authority in power will even attempt to do what they set him up to do. They do not even ask objectively what will actually be the effect of political measures they advocate, and of course it is not usually what they intend. But those who point out such unpleasant facts merely condemn themselves as temperamental reactionaries or corrupt. The screamers for compulsion sneer at the notion that freedom is a value ("freedom to exploit!" and "freedom to starve!") and do not reflect that their precious freedom to talk and to pass laws must closely follow general individual freedom of action (by mutual assent) into the discard. ${ }^{2}$

\section{II}

To the question, why do the intellectuals tend to believe in socialism, my own first impulse is to reply with the question: why single out, or "pick on" a) the intellectuals, and b) socialism. ${ }^{3}$ The scientific conception

I This phenomenon of waves, or fashions, in mass-thinking, feeling, and acting, and the role of leadership in this connection, is the main problem suggested by Hayek's article. It is matched by another craze conspicuous in public life at the moment-the stampede to change the course of history by rushing more and more billions of words onto more and more tons of paper through the printing press (now supplemented by getting them "on the air"). We are approaching a limiting condition in which everyone writes or talks, while no one reads or listens-since no one can do both at once-and of course no one will be playing the game whose rules are so hotly talked about. There is a pathetic failure to recognize the limits of intercommunication. Between two persons these are narrow, and there is a tendency toward predominantly one-way movement (not always from the woman to the man). And while one person can communicate to a large number, and with modern facilities, to the whole world, no skill or device will enable one to receive communication from more than one at a time. It is, again, largely this fact which underlies "leadership," and makes it the main phenomenon to be studied.

$=$ Of course reformers do not stop to inquire into their own motives; the result would be too unpleasant. Since, these days, the Freudian jargon inevitably creeps (or rolls) into any discussion of motives (other people's-note the accompanying articles on world government) there is one "complex" in human nature which ought to receive more attention than it does. It might be called the "Robin Hood Complex." It is the "drive" of A to correct "injustice" between $B$ and $C$-for a suitable cut; for Robin Hoods rarely serve God or The Poor for naught. To be governed by high-principled men (fanatics) or by plain ambitious power-seekers would be a serious choice. Napoleon abolished the Inquisition in Spain, and it was restored when his forces were driven out. It should be recognized that the main fault of the Bolsheviks is that they love justice and hate iniquity-like the great Pope, who was "therefore" dying in exile. The crux is that love of justice so commonly implies love of power (and its perquisites are seldom declined) as in both these cases. This was the real reason for the dying in exile; would that such were more likely to be the fate of all enemies of freedom.

3 In pointing out what seem to me serious shortcomings in Hayek's analysis of this problem, I wish it understood that no "idealogical" differences are involved, as far as I know. Both he and myself are "liberals," in the now largely antiquated meaning of the term, which once implied individual liberty, but has been generally turned upside-down to stand for state paternal- 
of explanation is to show that a particular phenomenon is an instance under a general principle the working of which is familiar in other cases. So, I should inquire, first of all, whether "in general" there is any presumption that human believing, or believing-in, will rest on intelligible and valid reasoning, or rather the contrary. With reference to the "intellectuals," the question is whether they really take the lead in the changes in "public opinion" which occur in history. Professor Hayek asserts that they do, but presents no evidence or supporting argument, and it seems to me that critical reflection makes one skeptical if not opposed. Even if the post-hoc could be established, and it is not, the propter-hoc would remain to be investigated. Logically, Hayek's own definition of the intellectual as a "middleman of ideas" excludes origination. They can at most select the ideas to be "pushed." Like any good merchant, they decide what will "go," so use persuasion (a form of coercion) in an effort to hasten its adoption and take the erudite. We surely know that it is hopeless to find the origin of any idea (Hayek repeatedly refers to new ideas but gives no example) either in time or place; all sorts of ideas are always "floating around," and indeed are always being pushed by intellectuals. The common ascription of great potency to advertising and propaganda is quite inconclusive; it is more likely that the leaders lead by being astute followers.

The real question is, what determines what will "go"; and all that can be said is that historians and social philosophers or scientists have been struggling and contending over that problem from the beginning, and nobody knows much about it, or anything very certainly. It is easy to credit a movement to the people who have been and are pushing it, but the fallacy is evident. The case of Aesop's rooster is parallel up to a point, but the social causality problem is more complex. One thing that can be said with confidence, about the leading genus of intellectuals, the journalists, and other "writers," is that they must not care very deeply and impartially about "truth," as judged by scientific or critical standards. One who does so will simply be eliminated by the process of natural selection, through market demand, by which the good writers are chosen. (What Hayek says

ism. And we both recognize that freedom is by no means the only value in social relations, even when (as old-style liberals have always taken for granted) freedom applies to both parties, and is to be guaranteed by law. Freedom without power (means, resources) is empty and it is also relative to wants or tastes, to both of which men have "rights." And much social action beyond free reciprocity, and voluntary giving, is required to secure a tolerable equality of burden and benefit between the strong and/or fortunate and the weak or unlucky, as well as to protect social values (the future) not adequately reflected in the interests of living and active individuals. All such issues are to be discussed on their merits-if those interested in them can get the time, away from struggling against merely stupid measures and propaganda. 
about recruitment of intellectual personnel seems to be rather superficial but I cannot go into detail.) And inspection of their output, even in the upper grades, will show that it is intended to be "interesting" or perhaps edifying, or, if "serious," that what is actually, literally said is mostly platitude, with some mixture of the absurd. The writers are opposed to sin and in favor of sweetness and light. And if they are really for or against anything in particular, it would be found to be a case of John Smith versus Jim Jones, or Tweedle-dum versus Tweedle-dee. (But these and not economic standards of living are the major human likes and dislikes, and major sources of happiness and discontent.) Even when "arguments" on both sides are presented, they have little bearing on any issue stated in terms defined to a point where one could "intelligently" take sides. Definition of terms is a bore-and, anyhow, it cannot be carried far since that would require measurement of imponderables. That many are elevated to the rank of good writers after they are dead only confirms this conclusion, and the relation of their message to "truth" remains tenuous.

With respect to public opinion and how it is made or explained, the main fact is clear: in matters moral and political, belief has little relation to truth or valid reasoning. Indeed, the question is rather why people so commonly profess to believe things that it is easy to see they do not-the most palpable contradictions and absurdities. And their actions commonly point to beliefs different from what they either say or think. ${ }^{4}$ Here we get to the crucial nature and problem of modern "liberal" civilization. The premise of its theory of social order is that men will arrive at truth-including all valid values-through discussion. This situation reflects the supreme spiritual revolution of history, an Umwertung aller Werte. Man is primarily a conventional animal, and when not conventional is primarily a romantic. He has to be the former because he is the latter; for it is indefinitely more important that a society be in agreement than that it agree on one thing rather than another. Custom and tradition have always formed the main substance even of technology, and vastly more so that of the mores. Societies have lived and prospered with the most diverse moral ideas and practices and social and political institutions, often disgusting or horrible to our finical tastes. They have also produced high civilization. The Greeks practiced infanticide "wholesale", worked slaves to death because replacement was cheap, and had standards of sexual

4 For example, turning the other cheek, or taking no thought for the morrow. Whoever said or did not say that he believed because it is absurd, or impossible, this is the only reasonable explanation for a lot of "believing." And of course it is of the essence of such beliefs to be beyond discussion; one who questions is simply wicked and to be dealt with as a criminal enemy - which does not mean he is to be loved. 
morality which we do not mention in public. Historically, truth and morals have meant what was established, and protected from critical scrutiny by sanctity and all the trappings of religion. "Thinking" has consisted of hammering at the eternal and immutable verities by the priest or, exceptionally, the bringing of a new revelation by some prophet. If anything was more right than custom, it was some older more primitive custom, from which the present typically shows a tendency to degenerate.

Moreover, evidence accumulates, especially in our own times (and from the past where the issue was given any trial, e.g., toleration of the Sophists in ancient Greece) that primitive man was right, that he instinctively knew "human nature" and realized that freedom of expression would mean disagreement, conflict, disintegration. And in so far as there is spontaneous agreement, the substance is usually some superstition or other romantic absurdity. Nowhere is this more strikingly true than in the field of economic activity and relations. We have to look for some historical explanation of the great "new idea" which underlies free society-that there is a presumption of mutual advantage in arrangements freely made by both parties, specifically exchanges in the open market. ${ }^{5}$ In this field all that is noteworthy is a momentary departure in the direction of rationality, with a violent relapse in our generation. We have seen excesses in the way of "protection" and monetary inflation which Adam Smith would not have imagined possible. We have, indeed, invented ingenious new techniques. But our main "new idea" for wasting labor and other resources, besides destroying freedom, is the resurrection of the medieval doctrine and practice of fixing a "just price" (wage, rent, etc.) by legislative and administrative fiat.

Fact and logic seem as impotent against the dictates of "fashion" in political-economic-ethical (not to mention religious) "belief" as in the case of neckties or Easter bonnets. The generations of "scientific" economic writing and teaching show no enduring effect; rather the reversions to type are increasingly endorsed by "economists" themselves, and are apparently well on the way to displacing the aberration of laisser-faire (free association) as orthodoxy, hence truth. And the visible effect of general education is to enable people to rationalize more ingeniously and literately their snap judgments based on prejudice.

5 One of two new things; the other is experimental science and technology. In these fields, modern civilization has seemed successful in departing from tradition as the norm. Here we do the crucial part of our thinking with our hands and eyes, not with our brains. Human biology is in an intermediate position between this area and the "moral sciences"; and the history of medical science and practice is not reassuring as to the prospects for an "objective" approach to social problems-particularly where illness and treatment involve "the mind." 
It would seem that a discussion setting out to examine the economic beliefs of the modern public might do well to glance at the traditions of our society in this field of "thinking." The facts are plain. To our religiousethical tradition, which is still generally accepted by profession, everything connected with business, trade, or money is sinful; and to our intellectual-esthetic or "cultural" tradition it is vulgar, sordid. The only purification from the contamination of wealth is to give it to "us"-whatever group dealing in the "higher values" happens to be talking. The connection of natural science is close enough to secure its condemnation as"materialistic," and abominable. As to economic science, that is of course all of these things; it is materialistic, vulgar, and sinful. Economists are without culture and in league with the exploiters. This theme might be developed at length but it would be without point.

I do wish my friend Hayek had seen fit to give his readers some indication of what he means, in his article, by "socialism." From other statements of his we know that he is by no means opposed to all positive political action in the economic field. He cannot even mean all "wrong" action, as he mentions protectionism in contrasting terms. He does not even mention communism. It seems to me that the issue as to why public opinion is so fallacious in economic matters should be discussed under several heads. In relation to policy, socialism should mean collectivism under democratic control; it should be distinguished on the one hand from "interventionism" and on the other from communism, i.e., dictatorship, ostensibly in the name of "the workers" or simply of justice. And above all, these notions about policy should be brought into relation with the basic misconceptions of the market organization (with state functions not opposed on economic or general ethical grounds), in which they are rooted. ${ }^{6}$

Most political intervention is demonstrably if not obviously stupid. This applies to substantially all price-fixing, to rationing particular goods (some exception for emergencies such as war) and to the great bulk of "regulation of industry" (exceptions for health measures, etc.). Where the machinery of the free market fails too badly and unavoidably, public provision is the rational recourse, i.e., taxation and social service or socialization (socialism). The last cannot be pronounced "demonstrably" bad. In

\footnotetext{
6 Under this last head, I will just mention two items. The relations of the market are not competitive, nor a matter of bargaining; the market is simply a system of free cooperation, and the only possible system on a wide scale. Second, it is not economy to destroy or waste in order to increase demand-as believed by our organized labor and farmer groups, and others. Professor Calvin Hoover tells how the late great economist J. M. Keynes (before he became a Lord) deliberately mussed up the clean towels in his hotel bath room saying he did it as a service to the U.S. economy. $5^{6}$ Jour. Pol. Econ. 397 , n. 12 (x948). This was during the depression of the 30 's and could be defended, assuming enough things to be "given."
} 
the individual case it may work better or worse than a voluntary organization form, depending on various conditions. General socialism is a matter of degree and kind, having no definite meaning, and competent opinion may differ widely in predicting the effects of any political arrangement. The major question regarding it (for a given political unit) is whether collectivism is compatible with democracy, or would occasion and require a dictatorship, to preserve order and secure reasonable efficiency.

The latter eventuality would mean "communism," or some politico-ecclesiastical corporativism. It is my impression-and who has more than an impression? - that this ideal, being more romantic, has more attraction for the intelligentsia than has socialism, in America, at this time. I say "this ideal" in the singular. Communism is arousing much furor at the moment, but that is largely because it is opposed especially by another organization "The Church" with practically the same principles. Differences in metaphysical professions have no relation to substantive issues, and for classless society one may read Kingdom of God (on earth as it was, to begin with). This opposition is fully as undemocratic in its own structure, employs the same propaganda methods (specifically, ungentle treatment of heretics), and agrees in condemning economic power and exalting prescriptive authority. (It may be given credit for not pretending to believe in democracy or individual liberty.) Apparently, it is only through such a stand-off rivalry between opposed totalitarianisms really differing only on who is to be boss, that freedom stands a chance to survive.

Here is the fundamental issue-freedom: are men in general more competent or less competent to judge their own well-being and manage their affairs (with social relations arranged by mutual assent) than some particular authority, or whoever will get into power if freedom is given up or frittered away? The modern doctrine of freedom is largely a reaction from that of original sin, coupled with the dogma that the Church has by divine appointment authority to define sin and punish or forgive sin, hence in general to manage the social order. When it was in power it acted partly through subservient secular agencies, but tended to rely increasingly on its own organs, legislature, and courts, and even executive.

\section{III}

Disregarding the specific reference to the intellectuals and to socialism and taking Hayek's article as a treatment of the reasons why "people" have foolish ideas particularly about economics, it is less open to criticism. This applies especially to the final section; also to the next-final, in which the author observes, quoting Lord Acton, that genuine lovers of freedom 
are always few. I would say intelligent lovers of freedom, and note that it is popularly loved only when men don't have it, and only under peculiarly oppressive despotism. To routine oppression and suppression they seldom object; indeed, this has been the normal state of society, backed up by religion; the typical attitude is to thank God for priest and prince and pray the divine blessing upon them. Philosophically the grave problem about freedom is set by the conditioning in infancy, or conversion in adult life, to feel free in being "led," and paying dearly for it, even being led to slaughter. But we cannot say that men are naturally, protoplasmically, orthodox and intolerant; again we have to consider our religious tradition which is peculiar in this respect. What men ought to do they must be forced to do, and think; no morality without religion; no religion without a church; no church without political organs to perform ruthlessly its every behest: such has been the "logic" of Christendom, for the most part, for approaching twenty centuries. After an interlude we seem to be reverting to it, the difference between Church and Party having become nominal.

Even more important, I think, is the scarcity of genuine love for truth, which (as already observed) is closely related to freedom in the liberal system of basic principles. But it is still more important, for the "truly genuine" lover of truth, that neither freedom nor truth can be treated as an absolute. They conflict with beauty and morality and other values, and with one another, necessitating "marginal" comparison and compromise, and correct proportioning. Nineteenth century liberalism tended to ignore this vital truth, for historical reasons and perhaps on the assumption that neither truth nor freedom would be overdone. But this is certainly not the case, particularly with reference to freedom in economic relations-as Hayek not only knows but admits and declares. Excessive freedom leads to cumulative growth in inequality and to concentration of power, and clashes with justice, in any definition. But justice is impossible, in any definition, and any serious attempt to achieve it will destroy all civilized life. It just isn't that kind of a world. The supreme romanticism is the idea that the universe is controlled by any force or principle with any special concern for human feelings or values. Nature is out for quantity of life, regardless of quality or kind. Man can rationally try only to correct some of the worst cruelties and injustices of the nature of things, and to minimize those which are inevitably added in raising standards all around, by a conspiracy against nature. If he attempts too much he will ruin everything, and the victims of injustice are better off with civilization than without it. The affliction of our age is not moral deterioration, as the religious and cultural carpers at modern liberal civilization are crying from 
the housetops. Rather, we have higher ideals and try to take them seriously, in contrast with "pie in the sky." Even religion itself is becoming dissatisfied with its role of opiate of the masses. The simple fact is that a good life, by the standards of our civilization, is possible for only a few, even in the wealthiest nations; and there is no just and possible way to select those who are to receive the major benefits and those who are to pay for them. Science and free speech have destroyed the religious "belief" that whatever is is right (or at least will be made right presently, in another sphere) and pseudo-science (especially social) has destroyed even the belief that it is necessary. The humanly natural reaction is a disposition to appeal to force, not to try to find and cure the evils that are actually remediable.

To sum up, and to end on a constructive note (another eleventh commandment), there is another way of answering Hayek's question with another. Why do the intellectuals believe economic nonsense?-why do economists make themselves absurd or pathetic by "teaching" the public things they would see without teaching if they were willing, and being unwilling, certainly will not be taught? Moreover, if "truth" is to be our fetish, might we not dig deep enough to face a little obvious truth about truth? Other values are usually more or less in conflict with truth, and there are fields in which it has nothing to do with the case, or is even a menace. In religion, for example, one must believe without questioning, or be eternally damned-and bring the same fate on others insofar as one has any influence. In economics also, we might apply the principle of credo quia absurdum-though probably not profess it too explicitly. Surely it is more important for society to agree, and hold together peaceably, than it is to agree on one thing rather than another. And for the individual, it is far better to think in the way one's fellow men "understand" and approve than to take seriously the foible-scruple of thinking correctly. Why should we pick out a few of the youth and try to make them anti-social, succeeding in a fraction of the cases?

So, my simple proposal is to drop the teaching of economics. I mean teaching by economists. Let everybody learn without molestation from those the great mass will learn from anyway-who but the intellectuals? And particularly that class well-stressed by Hayek, the specialists in other fields and primarily the other "social sciences," historians, sociologists, etc. But not forgetting lawyers and theologians, or natural scientists, nor journalists, novelists, and poets (in defiance of Plato). If treatises on and "courses" in "economics" are in demand (the word having much prestige) a qualification for the authors or teachers would be either a) not to have made any special study of the subject from the standpoint of facts and 
the way a free-market organization works, or b) to have the good sense to ignore any such findings in favor of what society wants to believe, will believe, and so ought to believe.

So, the final word should be, "beware of absolutes." Here again the honest thinker must advert to our religious tradition, with its tendency to erect an antithesis between right and might, or between the right and the expedient, with its absurd and monstrous maxim of "do right though the heavens fall." On the other hand, Talleyrand is said to have said that the only good principle is to have none. But like most bright or poetic sayings this also is "inaccurate." The right principle is to respect all the principles, but to take care to use good judgment as to which one to follow in any particular juncture-or, still more precisely, how far to follow any one and how far its opposite principle. There is always a principle, and a good principle, to be followed in any course of action, and used to justify that particular action. The ultimate besetting sin of the "intellectuals" is oversimplification-because it is that of those who elect them to interpret and formulate their own thinking. 